\title{
THE WALL
}

HASSNAA MOHAMMED

University of Wisconsin-Madison

\section{BRIEF}

On January 25, 2011, Egyptian youth protestors took to the squares and streets in all the major cities of Egypt, asking for "bread, freedom, and social justice." A few days after, when marches across Egypt ballooned, the protesting youth felt empowered to topple the oppressive Mubarak regime that had lasted for close to 30 years. In a collective effort, they gushed into Tahrir Square in downtown Cairo, and the streets in its vicinity, to ensure that their needs were known and to demand that they be met. The subsequent series of events included the first fair election in the modern history of Egypt, followed by the military coup.

Throughout these events, street art and social media became the main two mediums of public expression and news sharing. The walls of the streets surrounding Tahrir Square were very dynamic, changing with every new incident to communicate the tragedies that the state media refused to circulate. One of the walls, a wall on the street leading to Muhammed Mahmoud Street, was particularly interactive.

This poem addresses the resistance of the inspired youth protestors against the government before and after the military coup.

\section{REYWORDS}

revolution, protests, will

power, social justice, change, youth, art

Who would ever think that The Wall could see

in the midst of gas bombs, chants, and vendors brewing Egyptian tea?

Who would ever think that stillness could breathe?

Or that humanity could so shockingly freeze?

Who would ever think that the brush would not cease

to linger through adversity with no desire to appease?

Who would ever think that walls could narrate

the story of the youth that lived once to curate

a reality that seemed like a watercolor flake, essential to entrust and impossible to forsake?

With screams for "freedom, justice, and bread," 
shamelessly undressing the corpse of a government long ago dead,

the artist stood weary on a ladder, painting through chilly nights, withstanding the danger of demanding her legitimate rights,

negotiating with the stars for a glimpse of light, bruised by realizing the inevitable morning's plight.

Never did The Wall think it would prefer the night over the watchful soldier insisting to paint over it in white.

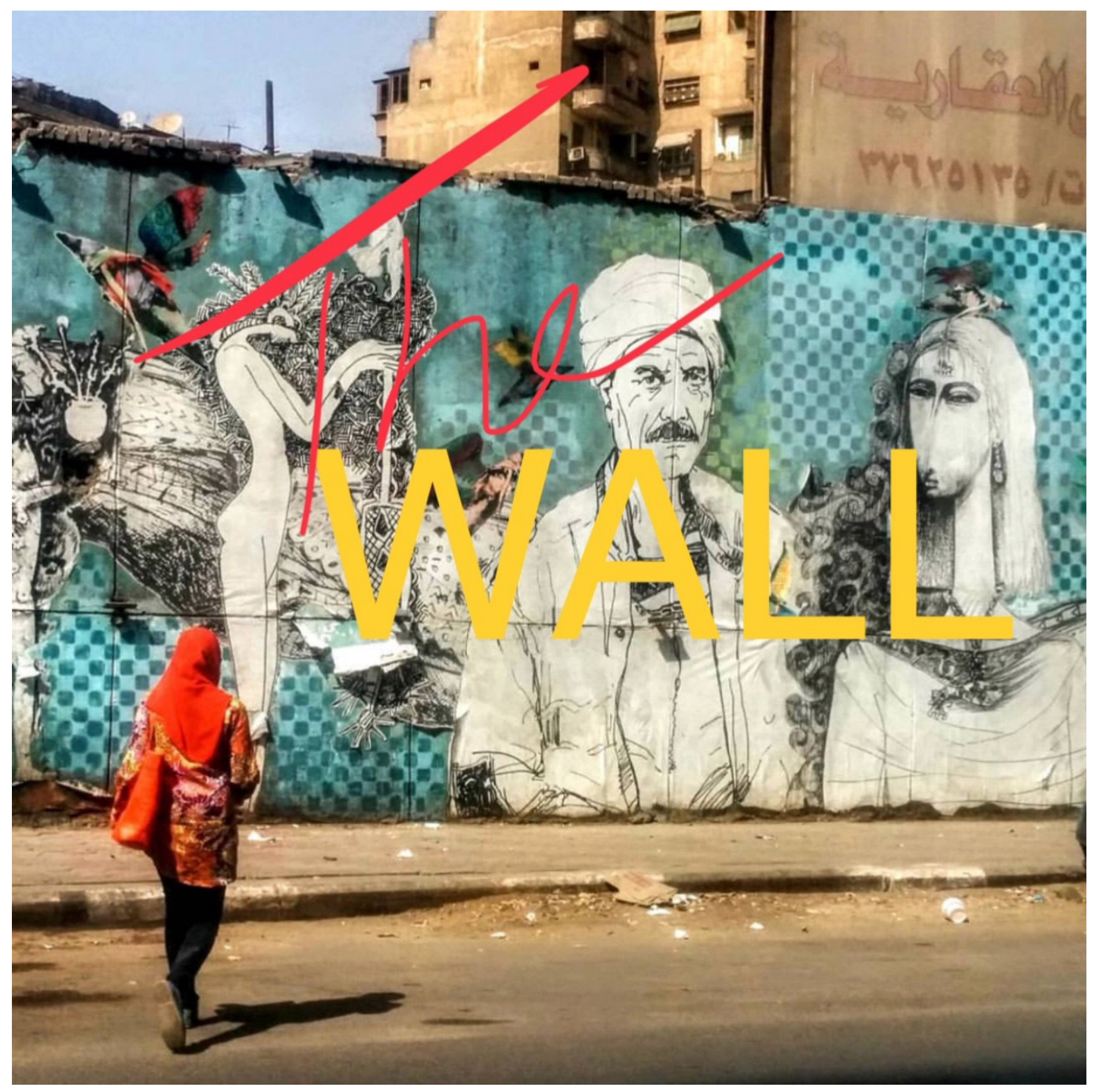

Wall graffiti on one of the streets in downtown Cairo. Photo by Hassnaa Mohammed. 